\title{
Application of Cooperative Learning Type Group Investigation to Improve Physics learning Outcomes in Vocational Schools
}

\author{
Meryana Benly ${ }^{1}$, Badrun Kartowagiran ${ }^{2}$, Luh Sukariasih ${ }^{3}$, Suritno Fayanto ${ }^{4, *}$ \\ ${ }^{1}$ Department of Master in Educational Research and Evaluation, Yogyakarta State University, Indonesia \\ ${ }^{2}$ Department of Educational Research and Evaluation, Yogyakarta State University, Indonesia \\ ${ }^{3}$ Department of Physics Education, Halu Oleo University, Indonesia \\ ${ }^{4}$ Senior High School Tahfidzul Qur'an Mu'adz Bin Jabal, Indonesia
}

Received June 22, 2020; Revised August 16, 2020; Accepted August 28, 2020

\section{Cite This Paper in the following Citation Styles}

(a): [1] Meryana Benly, Badrun Kartowagiran, Luh Sukariasih, Suritno Fayanto , "Application of Cooperative Learning Type Group Investigation to Improve Physics learning Outcomes in Vocational Schools," Universal Journal of Educational Research, Vol. 8, No. 10, pp. 4618-4627, 2020. DOI: 10.13189/ujer.2020.081030.

(b): Meryana Benly, Badrun Kartowagiran, Luh Sukariasih, Suritno Fayanto (2020). Application of Cooperative Learning Type Group Investigation to Improve Physics learning Outcomes in Vocational Schools. Universal Journal of Educational Research, 8(10), 4618-4627. DOI: 10.13189/ujer.2020.081030.

Copyright $\mathrm{C} 2020$ by authors, all rights reserved. Authors agree that this article remains permanently open access under the terms of the Creative Commons Attribution License 4.0 International License

\begin{abstract}
This study proposes to analyze the differences in learning outcomes of pupils, who learn cooperative learning models of group investigation and conventional learning. The research sample consisted of class $\mathrm{X}_{\mathrm{a}}(30$ people) who learned the cooperative learning model of the group investigation model and class $\mathrm{X}_{\mathrm{b}}(30$ people) taught using conventional learning models with the topic of learning is basic electronic (capacitors). The sampling technique uses random sampling with a non-equivalent control group design. Data collection techniques consisted of written tests, observation sheets and documentation. Meanwhile, research instrument used achievement test (objective criteria) in the form of multiple-choice questions that comprise as many as 25 of the given level $\left(\mathrm{C}_{1}\right)$, understanding $\left(\mathrm{C}_{2}\right)$ applying $\left(\mathrm{C}_{3}\right)$ and analyzed. Students' test results were analyzed using descriptive statistical data analysis and inferential statistical data analysis. The analysis results obtained that there is a difference of learning outcomes between the experimental class and a control class with an average of 80.8 to 69.6 for the control class and experimental class. From the analysis, it was found that there was no significant difference between the experimental and control classes based on the N-gain value. So it can be concluded that the group investigation learning model does not have a significant effect on improving student learning
\end{abstract}

outcomes.

Keywords Learning Outcomes, Capacitor, Vocational Study, Cooperative Learning Type Investigation, Physics Learning

\section{Introduction}

One of the obstacles faced by the world of knowledge is a subject of the weakness of the learning process. In the learning process, often, students are less encouraged to develop thinking skills [1][2]. The learning method in the classroom accentuate the child's capability to memorize information [3], [4]. So when students graduate from school, they do not have high creativity and innovation. In reality, this happens to all subjects that use conventional teaching of the same item [5].

The low quality of education can be interpreted as a lack of success in the learning process [6]. Learning is the heart of progressive education. The success of the learning process is influenced by various aspects one of which is the ability of teachers to create a learning atmosphere that can arouse students' motivation to participate in this learning [7][8][9]. Successful learning is characterized by an 
increase in student understanding for each subject.

Vocational high school is an educational institution at higher secondary level education unit that prepares students to expertise in specific areas to enter the workforce and supplies to continue their education at a higher level [10]. Schools directly linked to teaching and learning activities are needed to increase the efficiency of the learning process, both from equipment, services and human resources, in order to enhance the quality of the learning process and to produce qualified, successful vocational graduates.

The teacher's main role is to teach students, specifically to train students to actively learn so that their ability (cognitive, affective, and psychomotor) can optimally grow. With active learning by involvement in any learning activity, the students ' ability to do things that are good will eventually form a life skill as the provision of life [11]. For this to be realizing, the teacher should know how students learn to master different ways of teaching students.

Group learning can be more productive with practical work activities. Based on the content contained in the vocational school curriculum, it is inevitable that laboratory activities play an essential role in learning physics, especially in the electronics field. Practical work is a proper way not only to activate students but more to help students develop their competencies. Ismayanti [12] notes that the standard of vocational graduates poses many problems. Many research results show that the work ethics of vocational students is still unsatisfactory. Many of them are less able to do work, work together, create, collaborate and argue. To develop students' learning skills, therefore, a suitable alternative model of learning was required. So the teacher offers model of cooperative learning type investigation model with the assumption that the model is effective in improving student learning outcomes.

The type of cooperative learning model group investigation is a model of cooperative learning that based on a constructive illustration [13], [14]. A teacher as mediator or facilitator who helps the student in the learning process goes well [15]. This learning model retains the active engagement of students, where active involvement of the students can be seen from the first stage to the final learning level. Students involved in the preparation, both in deciding the subject and how to know it through on-the-spot analysis, presenting research finding [16], [17]. This type requires students to have the ability to think independently. Thus, learning is not only memorizing. Nevertheless, more than that, students truly understand and to able to apply the knowledge gained to solve problems, find something to wrestle with their ideas. The advantages of the Cooperative Learning Type Group Investigation model are as follows:

1. Personal in the learning process can work freely; give enthusiasm for initiative, creative and active; self-confidence can be further increasing; can learn to solve, handle a problem.
2. Socially improve learning to work together; learn to communicate both with friends and teachers; learning good communication systematically; learn to respect the opinions of others; increase participation in making a decision.

3. Academically trained students to take responsibility for the answers given; work systematically; develop and practice skills; plan and organize work; check the truth of the answers they make; always thinking about the method or strategy used so that a generally accepted conclusion is obtained.

In the Group Investigation model of learning, social interaction is a critical factor for the development of a new mental scheme [14], [17]. In cooperative learning, the teacher plays a role in giving freedom to students to think analytically, critically, creative, reflective and productive [18], [19]. Implementation of the cooperative learning strategy of Group Investigation in learning is generally divided into 6 (six) steps: (1) Identifying topics and organizing students into groups (students review information sources, select topics, promote information collection for teachers), (2) grouping, (3) conducting research (students finding knowledge, analyzing data, and drawing conclusions), (4) preparation of the final report, (5) presentation of the final report (presentations are made in different forms for the whole class), (6) evaluation (teachers and students work together in the evaluation of learning, assessments aimed at assessing conceptual understanding and critical thinking skills) [20]-[22]. Group investigation is a general planning plan where students work in small groups using helpful questions, group discussions, and cooperative design and projects. In the investigation group, students not only work together but also help plan the topic to be studied [23]. This teaching pattern will create the desired learning because students as learning objects are involved in determining to learn.

The character of this complex group Investigation learning is interesting to study and try to apply, especially in vocational schools for Visual-Audio majors. One of the topics taught in physics is capacitors. A capacitor is a device that stores charge [24]. Often, though not always, a capacitor consists of two electrical conductors (conductors) separated by a barrier (insulator) or dielectric capacitance. Based on observations made at the vocational school 2 Kendari, during the teaching and learning process, teachers only convey theories by linking daily life, but not with direct practice.

Some researchers who study the cooperative learning model of investigation type include [25], [26], and [27]. Derlina \& Hasanah [26] reported in their study that through the cooperative model of group type investment, the learning atmosphere was more effective. Cooperative relationships in study groups empower students to have the confidence to express their thoughts, connect with friends and exchange knowledge to solve learning problems. The same thing was founded in a study conducted by Santyasa 
[27] that the group investment model has a greater impact than the clear learning model in achieving critical thinking skills, social attitudes, moral attitudes and student character in high school physics learning sound waves and light waves. While Arinda [25] reported that the practical work skills of students using the PhET-based community study cooperative learning model in a useful 80.01 percent and 77.3 percent respectively. It indicated that learning to use the Community Investigation (GI) model with Phet allows learners skills for scientific research in both categories [25]. Sari [28] in her study reported that the learning results of physics with an investigation of a cooperative learning type investigations are higher than conventional learning. The learning results in physics with the ability to think logically above average are more important than students with the ability to think logically below average.

Based on the description that has been explained, the authors motivated to do a study with the title of the application of cooperative learning type group investigation to improve student learning outcomes. Therefore, the main objective of this study is (1) To find a description of student learning outcomes experimental class and control class before and after learning the subject matter of the capacitor; (2) To analyze the improvement in student learning outcomes between the group investigation class model and the traditional classroom model. Limitations of the problem in this study are to compare the results of student learning using cooperative learning models of group investigation type with conventional models in X class (consist of 60 students) of Vocational School 2 Kendari. Another one is the use of Cooperative learning model of group investigation type to improve learning outcomes on the topic of electronics basics (capacitor).

\section{Research Problems}

Based on the explanation that has been described in a research question, namely:

1. How is the description of the learning outcomes of the experimental class and control class students before and after learning on the topic of electronic basics (capacitor)?

2. Is there a significant difference between the pretest and posttest average scores of the experimental class with the pretest and posttest average scores of the control class students on the basic topics of electronics (capacitor)?

3. Is the $\mathrm{N}$-gain average value of the experimental class significantly better than the average value of the $\mathrm{N}$-gain control class?

\section{Methods}

\subsection{Research Type and Research Variable}

This study was included in the category of quasi-experimental. The variables in this study consisted of independent variables and dependent variables. The independent variable consists of classes taught by the Group Investigation cooperative learning model. In contrast, the dependent variable is physics learning outcomes.

\subsection{Population and Sample}

The population consisted of 2 parallel classes of class $X_{a}$ and $X_{b}$, after being tested using the homogeneity test. So the researchers took two classes consisting of class $X_{a}$ students and class $X_{b}$ students of Vocational School 2 Kendari. In this connection, the sample set to represent the entire population is 30 students in class $\mathrm{X}_{\mathrm{a}}$ and 30 students in $\mathrm{X}_{\mathrm{b}}$, so in total 60 students.

\subsection{Research Design}

The research design uses pretest-posttest control group design by dividing the class into two parts, namely the experimental class and the control class the experimental class was taught using a group investigation model. In contrast, the control class was taught using the traditional model (direct learning model)-research design in interpretation in Table 1.

Table 1. Research design

\begin{tabular}{|c|c|c|c|}
\hline Class & Pretest & Treatment & Post-test \\
\hline Experiment & $\mathrm{O}_{1}$ & $\mathrm{X}$ & $\mathrm{O}_{2}$ \\
\hline Control & $\mathrm{O}_{3}$ & $\mathrm{C}$ & $\mathrm{O}_{4}$ \\
\hline
\end{tabular}

Where,

$E=$ Experiment class

$K=$ Control class

$O_{I}=$ Pre-test experiment class

$\mathrm{O}_{2}=$ Post-test experiment class

$\mathrm{O}_{3}=$ Pre-test control class

$\mathrm{O}_{4}=$ Post-test control class

$X=$ Treatment given the experimental class that is the implementation of group investigation learning model.

$C=$ Treatment without cooperative learning

\subsection{Research Procedure}

The steps used in the study are presented as follows.

1. Conducting preliminary observations at a vocational school two population Kendari to determine the amount that will be the object of research, the value of capacitor material physics learning outcomes and learning model applied to the teaching process.

2. Retrieving the value of test data before the primary topic of the capacitor for the homogeneity test.

3. Determine the research sample using SPSS software to determine homogeneous populations.

4. Prepare the grating test.

5. Determine test questions that will be used in the final test on experimental and control classes that qualify based on the results of expert validation. 
6. Carry out pretest the control class and experimental class.

7. Conduct cooperative learning type Group Investigation (experimental class) and carry out conventional learning in class $\mathrm{X}$ (control class).

8. Perform posttest on an experimental class and control class.

9. Analyze the pretest and posttest.

10. Arrange of research results

\subsection{Data Collection Technique}

Data collection techniques in this study include: (1) written test that used to collect student learning outcomes data; (2) the observation that used to collect data that is held teacher learning process as the enforceability of teachers; and (3) documentation to obtain data on student learning outcomes into the study population before the learning process.

\subsection{Research Instrument}

The instrument that will be used to measure student physics learning outcomes in the form of achievement tests consists of 29 multiple choice objective test forms. The questionnaire instrument consisted of two choices. If the answer is correct, it will be one and false will be zero. The test given to the experimental group is the same as the test given to the control group. Learning outcomes measured are the cognitive aspect that is given $(\mathrm{C} 1)$, understanding (C2) applying (C3) and analyze.

\subsection{Data Analysis Techniques}

Data were analyzed using descriptive and inferential analysis. Descriptive statistics are using to describe the values obtained by each class in the form of average values, maximum values, minimum values and standard deviations. Furthermore, to determine the value of student learning outcomes, the range of values used for objective tests in this study is $0-100$ with the formula:

$$
S_{i}=\frac{S_{p i}}{S_{m}} \times 100 \%
$$

Where,

$S_{i}=$ the value obtained by the students to $-i$

$S_{p i}=$ scores obtained by students to $-i$

$S_{m}=$ The maximum score achieved

Whereas inferential analysis uses a test, the data was analyzed using Microsoft Excel and SPSS. In contrast, the inferential analysis consists of normality test, homogeneity and hypothesis testing. Hypothesis testing uses independent sample T-Test which is making in the following form:

1. Hypothesis 1
There is no significant difference between the average values of pretest student learning outcomes. Physics experimental class with the average value of pretest physics learning outcomes of control class students before learning on the subject matter of Capacitors.

$$
\begin{aligned}
& \mathrm{H}_{\mathrm{o}}: \mu_{1}=\mu_{2} \\
& \mathrm{H}_{1}: \mu_{1} \neq \mu_{2}
\end{aligned}
$$

Where,

$\mathrm{H}_{\mathrm{o}}=$ There is no significant difference between the average value of pretest student learning outcomes in the experimental class with the average value of pretest learning outcomes of control class students.

$\mathrm{H}_{1}=$ There is a significant difference between the average value of pretest student learning outcomes in the experimental class with the average value of pretest student learning outcomes control class

$\mu_{1}=$ The average value of pretest learning outcomes in experimental class students

$\mu_{2}=$ The average value of pretest learning outcomes in control class students

\section{Hypothesis 2}

The average value of the posttest results of students learning physics class experiment significantly better than the average value of the posttest learning outcomes physical control class in the subject matter of capacitors.

$$
\begin{aligned}
& \mathrm{H}_{\mathrm{o}}: \mu_{1} \leq \mu_{2 \backslash} \\
& \mathrm{H}_{1}: \mu_{1}>\mu_{2}
\end{aligned}
$$

Where,

$\mathrm{H}_{\mathrm{o}}=$ The average value of students ' posttest results in the experimental class is less than or equal to the results of the students' posttest average control class

$\mathrm{H}_{1}=$ The average posttest value of student learning outcomes in the experimental class is greater than the average posttest student learning outcomes of the control class

$\mu_{1}=$ The average posttest score of students' learning outcomes in the experimental class

$\mu_{2}=$ The average posttest score of the learning outcomes of the control class students

\section{Hypothesis 3}

The average of the $\mathrm{N}$-gain value results experimental class students learn physics significantly better than the average of the $\mathrm{N}$-gain value physics learning outcomes control class in the subject matter capacitor

$$
\begin{aligned}
& \mathrm{H}_{\mathrm{o}}: \mu_{1} \leq \mu_{2} \\
& \mathrm{H}_{1}: \mu_{\mathrm{g} 1}>\mu_{\mathrm{g} 2}
\end{aligned}
$$

Where,

$\mathrm{H}_{\mathrm{o}}=$ The average of $\mathrm{N}$-gain value student learning outcomes in the experimental class is less than or equal to the average $\mathrm{N}$-gain value student learning outcomes in the control class

$\mathrm{H}_{1}=$ The average value of $\mathrm{N}$-gain learning outcomes in experimental class students is higher than the average value 
of $\mathrm{N}$-gain learning outcomes of control class students

$\mu_{\mathrm{g} 1}=$ The average value of $\mathrm{N}$-gain learning outcomes of experimental class students

$\mu_{\mathrm{g} 2}=$ The average value of $\mathrm{N}$-gain learning outcomes of control class students

\section{Results}

\subsection{Result of Descriptive Analysis}

The results of the descriptive analysis of pretest, posttest, and $\mathrm{N}$-gain data for the experimental and control classes can be seen in Table 2 .

Table 2. Descriptive analysis of student learning outcomes

\begin{tabular}{|c|c|c|c|c|}
\hline \multirow{2}{*}{ Value } & \multicolumn{2}{|c|}{ Experiment class } & \multicolumn{2}{c|}{ Control class } \\
\cline { 2 - 5 } & Pretest & Post-test & Pretest & Post-test \\
\hline Average & 43,2 & 80,8 & 39,9 & 69,6 \\
\hline SD & 9,18 & 11,7 & 9,50 & 12,7 \\
\hline Maximum & 62 & 96 & 65 & 89 \\
\hline Minimum & 24 & 62 & 27 & 58 \\
\hline
\end{tabular}

Based on Table 2, it can be seen that the average value of learning outcomes of the subject matter of the capacitors of the experimental class students and the control class students both have increased. At the pretest, the lowest and highest values were founded in the two classes, namely the experimental class and the control class. At the time of the posttest, the second-lowest value reached different class, and the highest value contained in the experimental class. This increase is due to the group investigation learning model emphasizing student choice and control rather than applying teaching techniques in the room. In this model, students are given full control and choice to plan what they want to learn and investigate; students are placed in small groups. Each group is giving a different task or project.

Rutih et al., [29] states Group Investigation learning model can improve student learning outcomes better than conventional teaching methods. It is because the Group Investigation learning model can facilitate student learning in the topic chemicals in food so that learning outcomes are optimal. Fitriana [30] research results showed that students who were giving a cooperative learning model tipeGroup investigation had better academic achievement than students who were giving cooperative type STAD learning models.

Nonetheless, the average difference experimental class against class average nearing significant control. The average value grade students experiment and control class, as shown in Table 2, are presented in the form of Figure 1.

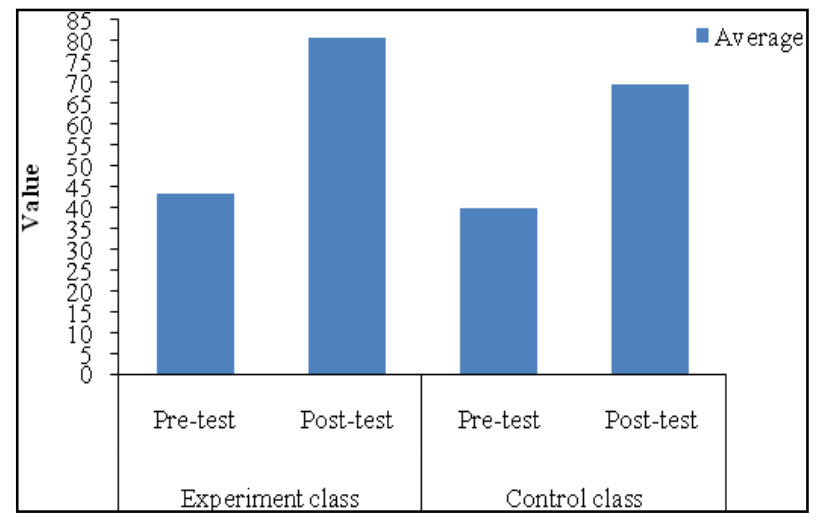

Figure 1. Graph of pretest and posttest mean score of the experimental class

Figure 1 shows that the average value of the pretest experimental class students was 43.2, and an increase in posttest with the average value obtained was 80.8 . Next, the two classes analyzed in the percentage for each category. Categorizing the pretest and posttest student experiment class and control class, see Table 3.

Table 3. Classifying learning outcomes between the experimental and the control class

\begin{tabular}{|c|c|c|c|c|c|c|c|c|c|}
\hline \multirow{4}{*}{ Value ratio } & \multirow{4}{*}{ Category } & \multicolumn{8}{|c|}{ Learning outcomes } \\
\hline & & \multicolumn{4}{|c|}{ Experiment class } & \multicolumn{4}{|c|}{ Control class } \\
\hline & & \multicolumn{2}{|c|}{ Pretest } & \multicolumn{2}{|c|}{ Post-test } & \multicolumn{2}{|c|}{ Pretest } & \multicolumn{2}{|c|}{ Post-test } \\
\hline & & $f$ & $\%$ & $f$ & $\%$ & $f$ & $\%$ & $f$ & $\%$ \\
\hline $0-40$ & Failed & 11 & 36,6 & 1 & 3,70 & 14 & 51,85 & 1 & 3,7 \\
\hline $41-55$ & Less & 15 & 55,5 & 2 & 7,4 & 14 & 51,85 & 3 & 55,56 \\
\hline $56-65$ & Enough & 3 & 11,11 & 5 & 18,51 & 0 & 0 & 9 & 33,33 \\
\hline $66-80$ & Good & 1 & 3,7 & 14 & 51,85 & 2 & 7,4 & 12 & 44,44 \\
\hline $81-100$ & Very good & 0 & 0 & 7 & 25,92 & 0 & 0 & 5 & 18,51 \\
\hline \multicolumn{2}{|c|}{ Total } & 30 & 100 & 30 & 100 & 30 & 100 & 30 & 100 \\
\hline \multicolumn{2}{|c|}{ Average } & & 42,4 & & 80,9 & & 41,6 & & 75,4 \\
\hline \multicolumn{2}{|c|}{ Standard deviation (SD) } & & 9,41 & & 11,7 & & 9,18 & & 12,7 \\
\hline
\end{tabular}

Information: $f$ :frequency 
Table 3 presents information that the pretest results of the experimental class students most of the students fall into the category of failing and lacking that both have the same percentage of $36.6 \%$ (11 students) and in the sufficient category of $11.11 \%$ ( 3 students) Good and very good category. There are no students in this category. Then the results of the posttest experimental class students explain most of the students included in the category of less with a percentage of $7.4 \%$ ( 2 students). Enough categories $18.51 \%$ (5 students), good category $51.85 \%$ (14 students), excellent $25.92 \%$ ( 7 students) and the category of failure was $3.70 \%$ ( 1 student). For more details, we are presented in graphical form as contained in Figure 2.

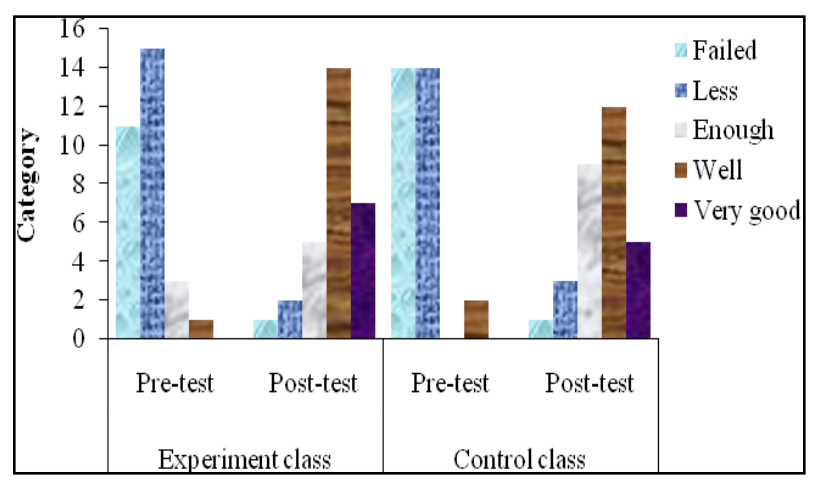

Figure 2. Graphs categorizing student learning outcomes

Based on Figure 2, it can be seen that the average results of the control class pretest are in the low category with a percentage of $51.85 \%$ (14 Students). Then for the results of the posttest of students in the control class students who fall into the category of fail $3^{\prime} 7 \%$ ( 1 person). Next, less category, $55.56 \%$ (3 students), enough $33.33 \%$ ( 9 students), good category $44,44 \%$ (12 students) and very good category $18.58 \%$ ( 5 students).

Furthermore, to see the significance of improving learning outcomes, the reference $\mathrm{N}$-gain value is used. We are categorizing $\mathrm{N}$-Gain subject matter of learning outcomes capacitor experimental and control classes presented in Table 3.

Table 4. Categorizing learning outcome-based N-gain Value

\begin{tabular}{|c|c|c|c|c|c|}
\hline \multirow{2}{*}{ Value } & \multirow{2}{*}{ Category } & \multicolumn{2}{|c|}{$\begin{array}{c}\text { Experiment } \\
\text { class }\end{array}$} & \multicolumn{2}{c|}{ Control class } \\
\cline { 3 - 6 } & & $f$ & $\%$ & $f$ & $\%$ \\
\hline $\mathrm{N}_{\text {Gain }}>0,70$ & High & 25 & 83 & 15 & 50 \\
\hline $0,30 \leq \mathrm{N}_{\text {-Gain }} \leq 0,7$ & Medium & 5 & 16 & 13 & 43 \\
\hline $\mathrm{N}_{\text {Gain }}<0,70$ & Low & 0 & 0 & 2 & 6 \\
\hline
\end{tabular}

Information, $f$ : Frequency

Based on Table 4, it can be said that the N-Gain category of learning outcomes of students' main capacitors both in the experimental class and the control class. Mostly falls into the medium category of 13 people $(43 \%)$ in the experimental class and five people $(16 \%)$ in the control class. In the experimental class, no student has the N-Gain value in the low category, five students in the medium category, or approximately $16.66 \%$, and 25 students in the high category, or $88.33 \%$. At no control class students who have the N-Gain value in the low category, two students in a category are 13 0rang or approximately $16.66 \%$ of students and 15 students in the high category of $50 \%$.

Therefore, in general, it can be said that the description of the N-Gain learning outcomes of the experimental class students mostly falls into the medium category with a percentage of $44.44 \%$. As for the N-Gain category, the learning outcomes of control class students were mostly in the low category, with a percentage of $59.26 \% . \%$.

\subsection{Result of Inferential Analysis}

a). Normality test

The The results of the normality test results of student learning outcomes that are obtained using the Kolmogorov-Smirnov test provided in Table 5 via the cooperative learning model type investigation.

Table 5. Results of data normality test

\begin{tabular}{|c|c|c|c|c|}
\hline & \multicolumn{2}{|c|}{ Kolmogorov-Smirnov $^{a}$} & $\alpha$ & Conclusion \\
\cline { 2 - 3 } & Statistik & $P$ & & \\
\hline $\begin{array}{c}\text { Experimen } \\
\text { class : pre-test }\end{array}$ & 0,145 & 0,110 & & \\
\hline $\begin{array}{c}\text { Experimen } \\
\text { class : post-test }\end{array}$ & 0,167 & 0,210 & \multirow{2}{*}{0,05} & $\begin{array}{c}\text { Data is } \\
\text { normality }\end{array}$ \\
\hline $\begin{array}{c}\text { Control class: } \\
\text { pre-test }\end{array}$ & 0,144 & 0,116 & & \\
\hline $\begin{array}{c}\text { Control class: } \\
\text { post-test }\end{array}$ & 0,142 & 0,127 & & \\
\hline
\end{tabular}

Table 5 indicates that significant value to the experimental class (pretest and posttest) of 0,167 dan 0.210 , which is higher than $\alpha=0.05$-thus concluded that the learning outcome data were studying through a normally distributed learning model. Similarly, in the control class (pretest and posttest), significant values are 0.116 and 0.127 , which is higher than $\alpha=0.05$. So it can be concluded that both the learning of each class learning with cooperative learning model type normally distributed group investigation at $\alpha=0.05$

\section{b). Homogeneity test}

Results of the homogeneity testing of data variance learning by group study learning models and traditional learning models written in Table 6

Table 6. The results of the data homogeneity test

\begin{tabular}{|c|c|c|c|}
\hline Data & $P$ & $\alpha$ & Conclusion \\
\hline Pretest & 0,526 & 0,05 & Data is homogeneity \\
\hline Post-test & 0,108 & 0,05 & Data is homogeneity \\
\hline
\end{tabular}

Table 6 shows that the significant value that is greater than $\alpha=0.05$. It can be concluded that the data pretest and 
posttest students are learning through cooperative learning model investigation group is homogeneous

\section{c). Hypothesis Test}

Hypothesis test was analyzed using SPSS software with T-test analysis. The following are the results of the hypothesis test analysis:

\section{Hypothesis 1}

The results of the T-test analysis of the pretest mean value of students learning through the cooperative group type investigative learning model and the conventional learning model are presented in Table 7.

Table 7. Hypothesis test results 1

\begin{tabular}{|c|c|c|c|c|c|c|}
\hline $\mathrm{N}$ & Average & $\mathrm{SD}$ & $\mathrm{dk}$ & $\rho$ & $\mathrm{A}$ & Conclusion \\
\hline 30 & 43,2 & 9,18 & \multirow{2}{*}{58} & 0,739 & 0,05 & $\mathrm{H}_{0}$ is accepted \\
\cline { 1 - 3 } 30 & 39,9 & 9,41 & & & & \\
\hline
\end{tabular}

Table 7 shows that the value of $\rho$ is higher, so it can be assumed that there is no substantial difference between the average value of student pretest learning by study group style cooperative learning models and traditional learning models

\section{Hypothesis 2}

The different test results of the average posttest scores of students learned through the cooperative group type investigative learning model and the complete traditional model of learning are presented in Table 8 .

Table 8. Hypothesis test results 2

\begin{tabular}{|c|c|c|c|c|c|c|}
\hline $\mathrm{N}$ & Average & $\mathrm{SD}$ & $\mathrm{Dk}$ & $\rho$ & $\alpha$ & Conclusion \\
\hline 30 & 80,8 & 13,44 & \multirow{2}{*}{58} & \multirow{2}{*}{0,0097} & 0,05 & $\mathrm{H}_{0}$ is rejected \\
\cline { 1 - 5 } 30 & 69,6 & 11,75 & & & & \\
\hline
\end{tabular}

From Table 8 it can be shown that the value of $\rho$ is lower than $\alpha=0.05$, so it can be inferred that there is a substantial difference between the average value of posttest students learning by study cooperative learning models type investigations and traditional learning models.

\section{Hypothesis 3}

The test results of N-Gain students learning through cooperative learning model investigation and conventional learning is presented in Table.

Table 9. Hypothesis test results 3

\begin{tabular}{|c|c|c|c|c|c|c|}
\hline $\mathrm{N}$ & Average & $\mathrm{SD}$ & $\mathrm{Dk}$ & $\rho$ & $\mathrm{A}$ & Conclusion \\
\hline 30 & 0,85 & 0,1272 & \multirow{2}{*}{58} & \multirow{2}{*}{0,0097} & 0,05 & $\mathrm{H}_{0}$ is rejected \\
\hline 30 & 0,82 & 0,1960 & & & & \\
\hline
\end{tabular}

Table 9 shows that $\rho$ is lower than $\alpha=0.05$, and it can be inferred that there is a substantial gap between the N-Gain scores of students studying by study forms of cooperative learning and traditional learning models.

\section{Discussion}

Based on the results of descriptive analysis (Table 5) on the pretest student learning outcomes with the average value obtained by the experimental class and control class students during the pretest, namely the experimental class was 43.2 and the control class 39.9. The low student learning outcomes before learning on the subject matter of capacitors caused by natural factors. Namely, the students who have tested have not gotten the subject matter about the capacitors in detail, so that their understanding and knowledge of the capacitor topics still very limited. The average yield of the pretest students showed that students' initial ability both to class experimental and control classes are statistically equal or homogeneous. So that both types can be treated differently, this result can also be proven inhomogeneity testing, which shows that both classes are comparable.

The physics learning outcomes did not show a significant difference (Table 2). It is likely to be influenced by the ability of students during the learning process. It is consistent with studies performed by [31] that there is substantial difference in students' learning outcomes in learning model implementation form of investigation with student learning outcomes in applying the Non-Group study to the learning triangle.

Furthermore, based on the results of the descriptive analysis it was seen that the increase in the average learning outcomes (N-gain) of the experimental class students was more significant than the average increase in the results (N-gain) of the control class students (Table 4). The average $\mathrm{N}$-gain of students in the experimental class increased by $59 \%$, while the gain of students in the control class $47 \%$. These tests correspond to inferential testing (Table 6), where inferential test results are at a confidence point of $95 \%$. Of course that the experimental class students' mean gain value did not indicate a substantial difference with the gain value of the control class student. This result proved by the value of $\rho$, which is smaller than the value of $\alpha=0.05$, which is 0.0097 .

A similar result was obtained from the results of the T-Test inferential analysis contained in SPSS 16.0 (Table 7, Table 8 and Table 9), confirming that the pretest results of students both taught through cooperative learning models of the type of investigation group (experimental class). Moreover, those taught using conventional learning models (control group) there is a significant difference, with the value $\rho=0.739$ higher than $\alpha=0.05$.

In testing the student's, posttest results showed that statistically there is a significant difference between the average value of the posttest students are learning with 
cooperative learning model of investigation with the average value of the posttest students learn through conventional study. In other words, it can be said that the average posttest value of students learn with the cooperative learning model of the investigative group is higher than the average posttest value of student study with conventional learning models. This result can be proved by $\rho$ value smaller than the value of $\alpha=0.05$ is 0.0097 . This increase is due to Group investigation helps teachers to link material with students' real situations and encourage students to apply knowledge in their lives [32]. In line with this, the research conducted by the Wahyuni et al.,[33] showed that the application of the investigation group was able to increase the interest and student learning outcomes and help students to apply their knowledge in life. Group investigation is one of the discovery-based cooperative learning methods where each group consists of 4-6 people with a heterogeneous group composition [34]. The steps of group investigation in learning are forming groups and selecting topics, planning the completion of topics, conducting investigations, preparing reports, presenting reports, and evaluating.

This result supported by a study conducted by [33] say that a group investigation model based on guided inquiry experiments is effective in increasing students' cognitive learning activities and outcomes on the topic of reflection compared to simple experimental methods. Whereas [14] described that the group investigation model could improve cognitive, psychomotor and effective learning outcomes of students. Furthermore, [35][21] related that cooperative learning type group investigation (GI) effectively applied to students' learning outcomes on the subject of optical devices that based on the results of the T-test obtained 1,965 results then $t_{\text {table }}=1.671$, with the provisions that if $\mathrm{t}_{\text {table }}<\mathrm{t}_{\text {count }}$ i.e. $(1,658<1,965)$. Whereas, [36] reported the results of the study showed that the Investigation learning method could improve students' critical thinking skills by $25.44 \%$. On the other hand, [37] states that there is a group investigation effect on students' conceptual understanding. While Astra et al. [38] report that the outcome of this research on quality aspects of learning-student-student interaction, teacher-student interaction, and learning outcomes, is about $75 \%$, according to the findings, it can be concluded that implementing cooperative learning type investigation can enhance learning processes and learning outcomes in physics science.

Therefore, the results of the study indicate that the cooperative learning model of investigative type using is very suitable for use in the learning process in which the ability of students actively participate in all aspects, make decisions to set the direction of the goals they are working.

\section{Conclusions}

From the description that has described conclusions of this research are: (1) The results of students learning physics after learning increased both for the experimental class and the control class. It indicated by the average acquisition of learning outcomes which increased from 42.4 to 80.9 for the experimental class and the control class from 41.6 to 75.4 ; (2) overview of learning outcomes using the group investigation learning model that is an increase in learning outcomes. Nevertheless, the increase is not significant between the two classes.

\section{Acknowledgments}

Researchers are very grateful to experts for their appropriate to Vocational School of 2 Kendari, which has facilitated researchers so that research can be resolved. The author would like thanks to Department of Master in Education Research and Evaluation for support and assisted so the study can be completed.

\section{REFERENCES}

[1] L. Sukariasih, A. S. Ato, S. Fayanto, L. O. Nursalam, and L. Sahara, "Application of SSCS model (search, solve, create and share) for improving learning outcomes: the subject of optic geometric," J. Phys. Conf. Ser., vol. 1321, no. 3, 2019, DOI: 10.1088/1742-6596/1321/3/032075.

[2] T. S. Ningsih, Abdurahman, D. Mardapi, and S. Fayanto, "Study on the effect of Core (connecting, organizing, reflecting and extending) learning model on mathematics learning outcomes of cognitive domain," Univers. J. Educ. Res., vol. 7, no. 11, pp. 2463-2471, 2019, DOI: 10.13189/ujer.2019.071125.

[3] W. R. Klemm, "What good is learning if you do not remember it?" J. Eff. Teach., vol. 7, no. 1, pp. 61-73, 2007.

[4] S. Fayanto, M. Musria, E. Erniwati, L. Sukariasih, and H. Hunaidah, "Implementation of quantum teaching model on improving physics learning outcomes in the cognitive domain at junior high school," IJIS Edu Indones. J. Integr. Sci. Educ., vol. 1, no. 2, pp. 131-138, 2019, DOI: 10.29300/ijisedu.v1i2.1958.

[5] M. Y. R. T. Kawuri, I. Ishafit, and S. Fayanto, "Efforts to improve the learning activity and learning outcomes of physics students with using a problem-based learning model,' IJIS Edu Indones. J. Integr. Sci. Educ., vol. 1, no. 2, pp. 105114, 2019, DOI: 10.29300/ijisedu.v1i2.1957.

[6] F. Fatmawati, L. Sukariasih, S. Fayanto, and H. Retnawati, "Investigating the effectiveness of inquiry learning and direct learning models toward physics learning," vol. 317, no. IConProCS, pp. 260-265, 2019, DOI: 10.2991/iconprocs-1 9.2019.54.

[7] Prasetyo Widyanto, "Penerapan metode pembelajaran group investigation berbantuan media flanelgraf untuk meningkatkan minat dan hasil belajar siswa pada mata pelajaran IPA," J. Pendidik. Dasar Nusant., vol. Vol. 3, no. No. 1, p. 12, 2017. 
[8] L. Sukariasih, A. S. Ato, S. Fayanto, L. O. Nursalam, and L. Sahara, "Application of SSCS model (Search, Solve, Create and Share) for improving learning outcomes: the subject of optic geometric," in Journal of Physics: Conference Series, 2019, vol. 1321, no. 3, DOI: 10.1088/1742-6596/1321/3/03 2075.

[9] M. Y. R. T. Kawuri and Suritno Fayanto, "Penerapan model discovery learning terhadap keaktifan dan hasil belajar siswa kelas X MIPA SMAN 1 Piyungan Yogyakarta Maria Yosephien," J. Penelit. Pendidik. Fis., vol. 5, no. 1, pp. 1-8, 2020.

[10] A. G. Tamrin, S. Slamet, and S. Soenarto, "The link and match of the demand and supply for productive vocational school teachers with regard to spectrum of vocational skills in the perspective of education decentralization," J. Pendidik Vokasi, vol. 8, no. 1, p. 40, 2018, DOI: 10.21831/jpv.v8i1.15135.

[11] M. Muslimin, S. Saleh, and M. Darwis, "Implementation of the use of lecture method in filing subjects at the department of office vocational school YPLP PGRI 1 Makassar," J. Adm. J. Pemikir. Ilm. dan Pendidik. Adm. Perkantoran, vol. 6, no. 2, p. 95, 2020, doi: 10.26858/ja.v6i2.11831.

[12] E. Ismayanti, "The design of collaborative learning for teaching physics in vocational secondary school," IOP Conf. Ser. Mater. Sci. Eng. 336, vol. 336, no. ICVEE 2017, pp. 111, 2018, DOI: 10.1088/1757-899X/336/ 1/012040.

[13] F. Eshetu, D. Gebeyehu, and M. Alemu, "Effects of cooperative learning method on secondary school students, physics achievement," Int. J. Multidiscip. Curr. Res., vol. 5, no. May, pp. 669-676, 2017.

[14] H. Yusniati and M. Yusuf, "Penerapan model pembelajaran kooperatif tipe group investigation untuk meningkatkan hasil belajar fisika hukum newton tentang gravitasi pada siswa kelas X1 IPA1 SMA Negeri 7 Kupang," J. Sains dan Pendidik. Fis., vol. 12, no. 1, pp. 1-13, 2016.

[15] Awaluddin, "Pembelajaran kooperatif tipe investigasi kelompok dengan penerapan software excel dan LKS untuk memahamkan persamaan," J. Pendidik. Sains, vol. 1, no. 1, pp. 65-71, 2013.

[16] M. Fadilurrahman, C. Ismaniati, and A. Mustadi, "Increasing student learning activeness through group investigation," J. Phys. Conf. Ser., vol. 1233, no. 012079, pp. $1-7,2019$

[17] W. A. U. Wardoyo and J M Sumilat, "Investigation group learning models on social sciences learning," J. Educ. Method Technol., vol. 2, no. 1, pp. 57-64, 2018.

[18] F. U. Nuha, D. Novita, and Bertha Yonata, "The development of student activity sheet (SAS) through cooperative learning model type group investigation (gi) to practice science process skill on matter of acid base for class XI," Unesa J. Chem. Educ., vol. 7, no. 2, pp. 167-173, 2018

[19] M. D. Wahyudi and G. Tripuspitaningrum, "Improving students learning outcome using group investigation model combined with think pair share and course review horay," Adv. Soc. Sci. Educ. Humanit. Res., vol. 274, no. 1, pp. 142 146, 2018, DOI: 10.2991/iccite-18.2018.32.

[20] E. Wijayanti, M. Firdaus, and hary Sulaksono, "Improving physics learning outcome through cooperative learning model of group investigation type and student learning motivation in SMAN 1 pesanggaran-Banyuwangi," Higher Education of Economic Mandala, pp. 30-39, 2016.

[21] D. R. Tobergte and S. Curtis, "Cooperative learning: theory \& practice," J. Chem. Inf. Model., vol. 53, no. 9, pp. 16891699,2013

[22] F. J. Irawan and N. Ningrum, "Pengaruh penggunaan model cooperative learning tipe group investigation (gi) terhadap hasil belajar prakarya dan kewirausahaan (pkwu) siswa kelas X semester genap SMK Negeri 1 Metro Tp 2015-2016," Promosi (Jurnal Pendidik. Ekon., vol. 4, no. 2, pp. 61-68, 2016.

[23] Mutiara, "Efek Model pembelajaran kooperatif tipe group investigation (GI) dan penguasaan materi fisika prasyarat terhadap hasil belajar fisika siswa SMA," J. Pendidik. Fis., vol. 3, no. 2, pp. 46-52, 2014.

[24] S. M. Zegeye, "A review paper on the study of charging and discharging the capacitor," Am. J. Quantum Chem. Mol. Spectrosc., vol. 3, no. 2, pp. 48-55, 2019, DOI: 10.11648/j.ajqcms.20190302.14.

[25] Y. Arinda, I. Wilujeng, and H. Kuswanto, "The Application group investigation (GI) learning model-assisted phet to facilitate student scientific work skills," Int. J. Educ. Res. Rev., vol. 4, no. 2, pp. 254-261, 2019, DOI: $10.24331 /$ ijere.518069.

[26] Derlina and N. Hasanah, "Influence of cooperative type model of group investigation on student $\mathrm{s}$ ' cognitive learning outcomes," Int. Conf. Scholarsh. Teach. Learn., vol. 1, no. 1, pp. 174-178, 2017.

[27] I. W. Santyasa, I. N. Kanca, I. W. S. Warpala, and I. K. Sudarma, "Group investigation and explicit learning models in learning physics at senior high schools," J. Penelit. Pengemb. Pendidik. Fis., vol. 5, no. 2, pp. 203-216, 2019, DOI: $10.21009 / 1.05216$.

[28] E. Sari, "Pengaruh model pembelajaran kooperatif tipe group investigation terhadap hasil belajar fisika ditinjau darikemampuan berpikir logis," J. Pendidik. Fis., vol. 6, no. 1, pp. 27-31, 2017.

[29] R. P. Dewi, R. S. Iswari, R. Susanti, and I. Artikel, "Penerapan model group investigation 1," Unnes Sci. Educ. $J .$, vol. 1, no. 2, p. 76, 2012.

[30] L. Fitriana, "Pengaruh model pembelajaran cooperative tipe group investigation (GI) dan terhadap prestasi belajar matematika ditinjau dari kemandirian belajar siswa," Universitas Sebelas Maret, 2010.

[31] L. Izzati, M. Kumar, and N. Priatna, "Application of investigation group learning model on triangle lesson," $J$. Phys. Conf. Ser., vol. 1157, no. 042066, pp. 1-7, 2019, DOI: 10.1088/1742-6596/1157/4/042066.

[32] A. T. Kesuma, Menyusun PTK Itu Gampang. Jakarta: Esensi, 2013.

[33] I. Wahyuningsih, Sarwi, and Sugianto, "Penerapan model kooperatif group investigation berbasis aktivitas belajar," Unnes Phys. Educ. J., vol. 1, no. 1, pp. 1-6, 2012.

[34] Rusman, Model-model pembelajaran. Depok: PT Rajagrafindo persada, 2012. 
[35] N. Akly and A. Halimah, "Efektivitas penerapan model pembelajaran kooperatif tipe group investigation (gi) terhadap hasil belajar fisika," J. Pendidik. Fis., vol. 3, no. 1, pp. 1-13, 2016.

[36] E. Lestari, H. Cahyono, and A. Awaluddin, "Penerapan model pembelajaran group investigation pada materi lingkaran untuk meningkatkan kemampuan berpikir kritis," J. Math Educ. Nusant., vol. 5, no. 2, pp. 124-139, 2019, doi: 10.29407/jmen.v5i2.12814.
[37] H. V. Sinaga and Togi Tampubolon, "pengaruh model pembelajaran kooperatif tipe Group investigation terhadap pengetahuan konseptual siswa pada materi usaha dan energi," J. Inov. Pembelajaran Fis., vol. 2, no. 7, pp. 1-6, 2019.

[38] I Made Astra, C. Wahyuni, and H. Nasbey, "Improvement of learning process and learning outcomes in physics learning by using collaborative learning model of group investigation at high school (grade X, SMAN 14 Jakarta )," J. Educ. Pract., vol. 6 , no. 11, pp. 75-80, 2015. 